\title{
A video demonstration of a prominent jugular venous pulse in a case of atrial septal defect
}

\author{
Monika Pathania, ${ }^{1}$ Bhagat Singh Lali, ${ }^{2}$ Vyas Rathaur ${ }^{3}$
}

${ }^{1}$ Department of Internal Medicine, VCSG Government Medical Sciences \& Research Institute, Srinagar (Garhwal), India

${ }^{2}$ VCSG Government Medical Sciences and Research Institute, Srinagar (Garhwal), India

${ }^{3}$ Department of Pediatrics, VCSG Government Medical Sciences \& Research Institute, Srinagar (Garhwal), India

\section{Correspondence to}

Dr Bhagat Singh Lali, lali_dreams@yahoo.com
To cite: Pathania $\mathrm{M}_{\text {, }}$ Lali BS, Rathaur V. BMJ Case Reports Published online: [please include Day Month Year] doi:10.1136/ bcr-2012-008211

\section{DESCRIPTION}

A case of prominent jugular venous pulse (JVP) with a clear wave pattern and the echocardiography of the condition responsible is discussed. A 63-year-old woman living in a hilly region presented to us with a 20-day history of orthopnoea and swellings in her legs and a 1-year history of exertional dyspnoea and palpitations. She had a 1-year history of New York Heart Association (NYHA) class III cardiac failure and was being treated at a local hospital with diuretics for dilated cardiomyopathy. For the last 15 days she was finding it difficult to walk up hills. On physical examination, she had an elevated JVP with visible large ' $a$ ' and ' $v$ ' waves with fusion, which was prominent even in the sitting position (video 1), and a displaced apex beat in the sixth intercostal space. She had a left parasternal heave and a murmur caused by tricuspid regurgitation. She had a wide and fixed S2. Her chest x-ray revealed

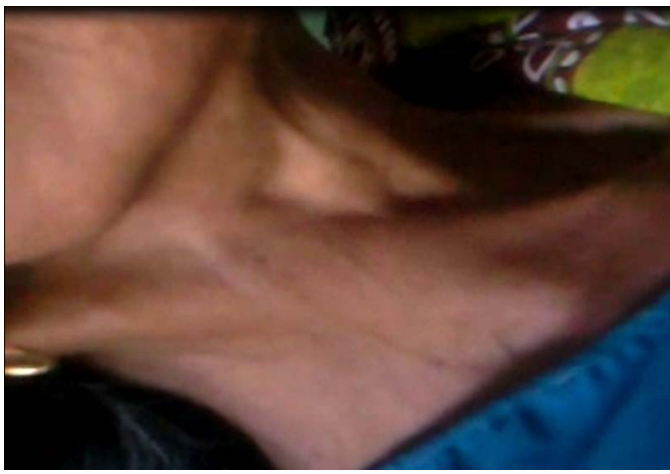

Video 1 Video demonstration of a prominent jugular venous pulse cardiomegaly (figure 1) and 2D echocardiography showed a large atrial septal defect with significant left to right shunt and pulmonary hypertension with the 'matchstick' sign (figure 2).

The ' $\mathrm{v}$ ' wave reflects the passive increase in pressure and volume of the right atrium as it fills in late systole and early diastole. Normally the crests of the ' $\mathrm{a}$ ' and ' $\mathrm{v}$ ' waves are approximately equal in amplitude. ${ }^{1}$ In patients with an atrial septal defect, the higher left atrial pressure is transmitted to the right atrium and ' $a$ ' and ' $v$ ' waves are equal or the ' $v$ ' wave is larger than the ' $a$ ' wave. ${ }^{2}$ Other

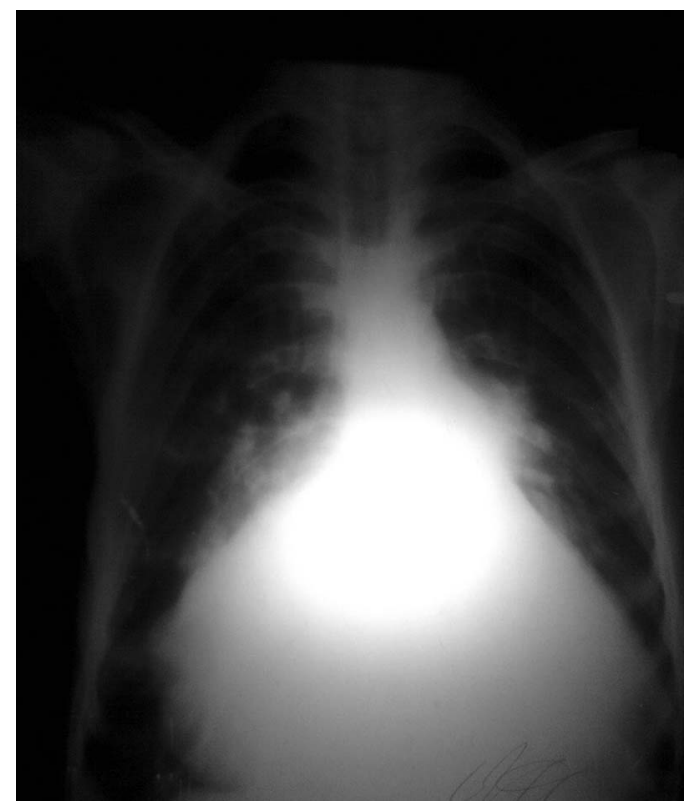

Figure 1 Chest x-ray showing cardiomegaly.

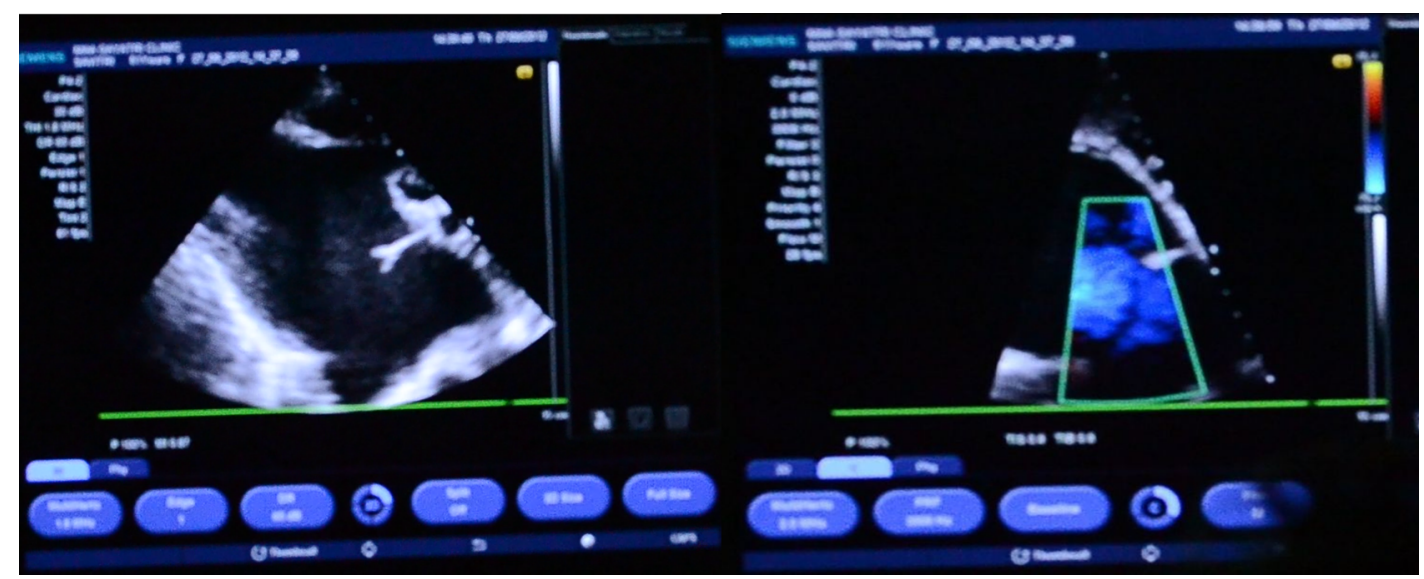

Figure $2(A, B)$ Echocardiography showing the 'matchstick' sign with blood gushing from the left to right atrium. 
conditions producing a prominent JVP are tricuspid regurgitation and constrictive pericarditis. ${ }^{3}$

\section{Learning points}

A raised jugular venous pulse with ' $v$ ' waves of higher amplitude than the 'a' waves can be seen in conditions such as atrial septal defect, tricuspid regurgitation and constrictive pericarditis.

- The collapse in neck veins is the most dramatic movement and should be timed when determining the type of wave.

- Prominent jugular venous pulse in an adult with symptomatic ASD denotes severe pulmonary hypertension.
Competing interests None.

Patient consent Obtained.

Provenance and peer review Not commissioned; externally peer reviewed.

\section{REFERENCES}

1 Applefeld MM. The jugular venous pressure and pulse contour. In: Walker HK, Hall WD, Hurst JW. eds. Clinical methods: the history, physical and laboratory examinations. 3rd edn. Boston: Butterworths, 1990. Chapter 19. http://www.ncbi. nlm.nih.gov/books/NBK300/ (accessed 18 Jan 2013).

2 O'Rourke RA, Silverman ME, Sellant RC. General examination of the patient. In: Schlant RC, Alexander RW, eds. Hurst's the Heart, 8th Edn. New York: McGrawHill, 1994.

3 Short DS. The jugular venous pulse. Postgrad Med J 1957;33:389-93.

Copyright 2013 BMJ Publishing Group. All rights reserved. For permission to reuse any of this content visit http://group.bmj.com/group/rights-licensing/permissions.

BMJ Case Report Fellows may re-use this article for personal use and teaching without any further permission.

Become a Fellow of BMJ Case Reports today and you can:

- Submit as many cases as you like

- Enjoy fast sympathetic peer review and rapid publication of accepted articles

- Access all the published articles

- Re-use any of the published material for personal use and teaching without further permission

For information on Institutional Fellowships contact consortiasales@bmjgroup.com

Visit casereports.bmj.com for more articles like this and to become a Fellow 